\title{
Design of Scientific Research Performance Evaluation System in Application-oriented Universities Based on Balanced Scorecard
}

\author{
Wan Wang \\ Jiangsu University of Technology \\ Changzhou, China 213001 \\ Shaoyi Bei \\ Jiangsu University of Technology \\ Changzhou, China 213001
}

\author{
Yinzhong Yang \\ Jiangsu University of Technology \\ Changzhou, China 213001 \\ Jianwen Wang \\ Jiangsu University of Technology \\ Changzhou, China 213001
}

\begin{abstract}
Performance evaluation of scientific research is an important way to effectively improve comprehensive strength, applied research level and innovative development ability of application-oriented universities. In the work, we analyzed evaluation principle of scientific research performance in application-oriented universities based on the Balanced Scorecard (BSC) theory. Scientific research performance evaluation system was built from four dimensions to externalize strategy and target of scientific research development, providing beneficial reference for scientific research performance evaluation in application-oriented universities.
\end{abstract}

Keywords-balanced scorecard (BSC); application-oriented universities; scientific research performance; index system

\section{INTRODUCTION}

With rapid development of economy and society in China, the economy has entered "the new normal", demanding for the cultivation of applied innovative talents in universities. Thus, application-oriented universities become the important position for applied innovative talent cultivation. Scientific research leads the teaching for support. The integration of scientific research and teaching is one of important ways to train applied innovative talents in colleges in the new era. Scientific research can be transformed from low to high efficiency through efficient scientific research, contributing to improving the levels of college teaching and talent cultivation. Characteristic discipline construction is developed to optimize subject structure, teaching content and method, thus promoting prosperous development of public entrepreneurship and innovation.

Scientific research performance evaluation is an important way to effectively improve comprehensive strength, applied research level and innovative development ability in application-oriented universities. The property of application-oriented university determines that scientific research focuses on application. However, the scientific research strength is still weak because the teachers are short of enthusiasm, with little achievement transformation and uncertain management direction. These problems become important factors of hindering the development of application-oriented universities. Therefore, it is necessary to deeply analyze scientific research management work in application-oriented university, especially the performance evaluation method of scientific research. Therefore, teacher's enthusiasm of scientific research is aroused to increase the quality of teacher team, thus promoting teaching level and comprehensive strength of application-oriented university.

\section{Performance EVAluation OF SCIENTIFIC}

RESEARCH MANAGEMENT IN BSC AND APPLICATIONORIENTED UNIVERSITIES

\section{A. Survey of BSC}

As a performance evaluation system, BSC was proposed by Robert Kaplan (Professor of Harvard University) and David Norton (CEO of Nolan Norton Institute) in early 1990s. After decades of evolution, it develops into comprehensive performance evaluation system and control tool of organizational strategy formulation and implementation. BSC is widely used in performance management of enterprises and universities, providing the thinking model from strategy to action plan. According to finance, customer, internal operation, learning and growth, BSC externalizes development strategy, vision and mission of scientific research development to form specific targets and evaluation indicators. Therefore, the staffs and strategy targets are directly connected to become dynamic management mechanism of strategy implementation and monitoring.

\section{B. Performance Evaluation Content of Scientific Research Management in Application-oriented Universities}

In application-oriented universities, BSC is applied in the scientific research management to enhance the scientificalness and benefit of scientific research 
performance evaluation. Traditional design of scientific performance evaluation index has disadvantages including complexity, uncertain objective and poor operability, thus causing low effectiveness, reliability and feasibility of scientific research performance evaluation. The content of scientific research performance evaluation in applicationoriented universities contains four dimensions including research funding, benefit, efficiency, learning and growth of researchers. The professional practice and technical development are highlighted to build an operational, interrelated, causal evaluation system in application-oriented universities.

In application-oriented universities, the dimensions of BSC are not isolated, forming a dynamic organic whole of causality. The goal of scientific research management is to improve the output and conversion rate of scientific research. Colleges should constantly adjust the internal management process to increase the efficiency and quality of internal research management and implementation, thus improving the output. Therefore, the causal connection among the four dimensions shows that the finance (investment and utilization of scientific research funding) affects the benefit and efficiency of achievements (output and conversion rates) as well as learning and growth (development, learning, communication and title assessment of researchers). Four casual, interrelated dimensions (finance, efficiency, efficiency, learning and growth) commonly determine scientific research performance evaluation in applicationoriented universities. "Fig. 1" shows the BSC model.

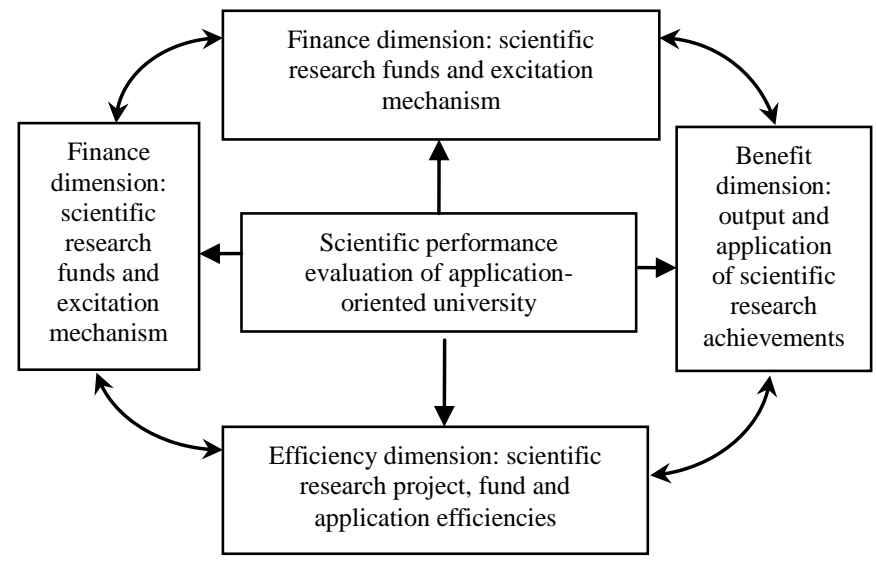

Fig. 1. BSC model in application-oriented university

\section{PRINCIPLE OF SCIENTIFIC RESEARCH PERFORMANCE EVALUATION IN APPLICATION-ORIENTED UNIVERSITY BASED ON BSC}

\section{A. Evaluation Results to Manifest Scientific Research Responsibility and Effectiveness}

In application-oriented universities, scientific research performance evaluation by BSC aims at evaluating the contribution degree of staff to research strategy goal rather than simply replacing traditional performance evaluation method. Therefore, the evaluation results should reveal scientific research responsibility and effectiveness in BSCbased performance evaluation.
The scientific research responsibility and effectiveness of the faculty are reflected in three aspects. The first is scientific research performance. These kinds of figures are analyzed to find their true meanings. E.g., there is large difference between numbers (1 and 1,000) of the writings. However, the key of evaluation is whether there is an innovative idea, and which level are the writings at. The second is the energy that the staffs devote to scientific research team. Without independent research results, some staffs still play important roles in assisting in scientific research teams. We can make evaluation by understanding the situations when the team members are acting as the host, partner and assistant. The third is the contribution degrees of teaching staffs to scientific research of students and departments. The students can evaluate the contribution of teaching staffs and those who provide supplementary voluntary labor of scientific research for professional colleges.

\section{B. Evaluation Standard to Manifest the Credibility of Scientific Research Management}

In application-oriented universities, scientific research performance evaluation by BSC focuses on key events, morality, ability, duty and achievement of teaching staffs. The index systems of four dimensions comprehensively reflect scientific research quality, ability, attitude and performance of teaching staffs. Scientific research performances of teaching staffs are reflected by different evaluation standards including thinking quality, special ability and real achievement of staffs in scientific research. Scientific method is used to reveal decomposition ability and credibility of scientific research management department to research strategy, thus increasing the attraction to staffs. Therefore, evaluation standards should manifest credibility and attraction of scientific research management in colleges.

This credibility is mainly reflected in five aspects. Firstly, the evaluation index cannot be omitted. Evaluation Indexes and corresponding standards are mutually complementary to form a complete assessment system. Secondly, the premises of evaluation standards are consistent. In the formulation of BSC index systems and evaluation standards, the relevant provisions of design specifications at different levels should have distinct conversion and the same standard. Thirdly, the evaluation standards are mutually connected. The four levels of BSC index system are hierarchical. Therefore, the specific indexes formed by decomposition of each layer are connected and coherent with each other; otherwise, it will easily lead to confusion of teaching staffs in scientific research. The fourth is the quantification and refinement of evaluation. The indexes are refined at all levels to ensure the fairness of scientific research performance evaluation. Through quantitative indexes, the evaluation of scientific research management is easily believed to be objective and regular, thus reducing dissatisfaction and resistance of teaching staffs. Fifthly, the evaluation standards are formulated in group rather than individuals, which is different from BSC index system. According to the characteristics of teaching staffs at different levels, specific evaluation indexes are formulated to achieve collective and targeted assessment. 


\section{Evaluation Process to Manifest the Feedback of Scientific Research Evaluation in Colleges}

BSC is used for the implementation process of scientific research performance evaluation in application-oriented universities. The effectiveness of scientific research performance evaluation depends on the relevant feedback follow-up measures. Therefore, scientific research performance evaluation based on BSC should ensure the process can reflect the feedback of scientific research evaluation in colleges. There are examples including staff research activity follow-up, the timeliness of performance guidance, reward and punishment feedback and modification after evaluation. Scientific research assistance is provided in time according to the evaluation process. Scientific research management departments in application-oriented universities achieve final evaluation effect of scientific research performance through the feedback link design of the evaluation process.

In addition, scientific research performance evaluation, reward and punishment based on BSC should also be designed in the collection link of feedback information. Scientific performance managers should be widely aware of the dissatisfaction of teaching staffs to BSC evaluation process, thus finding out the reasons. If the dissatisfaction of staffs cannot be relieved, it will affect their research behaviors. Therefore, colleges can set up complaint procedure of BSC performance appraisal to provide the staffs with smooth channel and platform for complaints. Reasonable complaint issues are introduced into adjustment directory of scientific research performance evaluation in universities. By solving the complaints according to the training program, we gradually enhance staffs' recognition to scientific strategy and initiative, thus highly integrating personal goal with overall research goal in college.

\section{INDEX DESIGN OF SCIENTIFIC RESEARCH PERFORMANCE EVALUATION IN APPLICATION-ORIENTED UNIVERSITY}

\section{A. Index System Design}

1) Financial dimension: Financial index is an indispensable part and the core of traditional performance evaluation system. As important guarantee of scientific research in university, financial index comprehensively reflects scientific research performance in applicationoriented universities. Financial index consists of 2 secondlevel (such as scientific research funds and investment) and 7 third-level indexes (such as national project funding, per capita research funding, the proportions of book information investment and construction investment for scientific research innovation team) in "Table I".

TABLE I. EVALUATION INDEX OF FINANCIAL DIMENSION

\begin{tabular}{|c|c|c|c|}
\hline $\begin{array}{l}\text { First-level } \\
\text { Index }\end{array}$ & $\begin{array}{l}\text { Second- } \\
\text { level } \\
\text { Index }\end{array}$ & Third-level Index & Weight \\
\hline \multirow{7}{*}{$\begin{array}{l}\text { Financial } \\
\text { Dimension } \\
(0.2)\end{array}$} & \multirow{4}{*}{$\begin{array}{l}\text { Research } \\
\text { Funding } \\
(0.1)\end{array}$} & $\begin{array}{l}\text { National Project Funding }(10,000 \\
\text { Yuan) }\end{array}$ & 0.040 \\
\hline & & $\begin{array}{l}\text { Project Funding at Province and } \\
\text { National Association Level }(10,000 \\
\text { Yuan) }\end{array}$ & 0.030 \\
\hline & & $\begin{array}{l}\text { Project Funding at City Level } \\
(10,000 \text { Yuan })\end{array}$ & 0.015 \\
\hline & & $\begin{array}{l}\text { Per Capita Research Funding for } \\
\text { Teacher }(10,000 \text { Yuan })\end{array}$ & 0.015 \\
\hline & \multirow{3}{*}{$\begin{array}{l}\text { Research } \\
\text { Investment } \\
(0.1)\end{array}$} & $\begin{array}{l}\text { Investment Ratio of } \text { Book } \\
\text { Information }(\%)\end{array}$ & 0.030 \\
\hline & & $\begin{array}{lcc}\text { Investment Ratio of } & \text { Instrument, } \\
\text { Equipment } & \text { and } & \text { Laboratory } \\
\text { Construction }(\%) & \end{array}$ & 0.030 \\
\hline & & $\begin{array}{lcr}\text { Investment } & \text { Ratio of } & \text { Scientific } \\
\text { Research } & \text { Innovation } & \text { Team } \\
\text { Construction }(\%) & & \end{array}$ & 0.040 \\
\hline
\end{tabular}

2) Benefit dimension: Benefit dimension embodies development strategy and target of application-oriented universities. It mainly evaluates scientific research output, innovation ability and satisfaction degree to scientific research management. The evaluation index consists of 6 second-level (such as scientific research project, paper, service satisfaction, scientific and technical awards) and 20 third-level indexes (such as national research project, domestic \& foreign core journals, citation times of papers, invention patent, total income of intellectual property or technology transfer, various scientific research awards, satisfaction degree of scientific research service, attention degrees of governments at all levels, ratios of key disciplines at national and provincial levels) in "Table II".

TABLE II. EVALUATION INDEX OF BENEFIT DiMENSION

\begin{tabular}{|c|c|c|c|}
\hline First-level Index & Second-level Index & $\begin{array}{l}\text { Third-level Index } \\
\end{array}$ & Weight \\
\hline \multirow{13}{*}{$\begin{array}{l}\text { Benefit } \\
\text { Dimension } \\
(0.3)\end{array}$} & \multirow{3}{*}{$\begin{array}{l}\text { Scientific Research Project } \\
(0.045)\end{array}$} & National Scientific Research Project & 0.023 \\
\hline & & Scientific Research Project at Province and National Association Level & 0.014 \\
\hline & & Scientific Research Project at City Level & 0.009 \\
\hline & \multirow{5}{*}{$\begin{array}{l}\text { Paper } \\
(0.06)\end{array}$} & International Authoritative Journal (IF $\geq 1)$ & 0.024 \\
\hline & & Domestic Authoritative Journal ( $\mathrm{IF} \geq 1)$ & 0.015 \\
\hline & & EI Source Retrieval or Authoritative Journal Reprint & 0.009 \\
\hline & & Core Journal & 0.006 \\
\hline & & Citation Times of Papers & 0.006 \\
\hline & \multirow{2}{*}{$\begin{array}{l}\text { Work } \\
(0.045)\end{array}$} & Work & 0.023 \\
\hline & & Work (1 Thousand Words) & 0.023 \\
\hline & \multirow{2}{*}{$\begin{array}{l}\text { Patent and Intellectual Property Right } \\
(0.06)\end{array}$} & Invention Patent & 0.036 \\
\hline & & Total Income of Intellectual Property or Technology Transfer & 0.024 \\
\hline & Scientific and Technical Awards (0.06) & First, Second and Third Prizes in State Natural Science Award & 0.015 \\
\hline
\end{tabular}




\begin{tabular}{|c|c|c|c|}
\hline First-level Index & Second-level Index & $\begin{array}{l}\text { Third-level Index } \\
\end{array}$ & Weight \\
\hline \multirow{7}{*}{$\begin{array}{l}\text { Benefit } \\
\text { Dimension } \\
(0.3)\end{array}$} & \multirow{4}{*}{ Scientific and Technical Awards (0.06) } & First, Second and Third Prizes in State Technological Invention Award & 0.015 \\
\hline & & $\begin{array}{l}\text { First, Second and Third Prizes in State Scientific and Technological } \\
\text { Progress Award }\end{array}$ & 0.015 \\
\hline & & $\begin{array}{l}\text { First, Second and Third Prizes in Provincial Level Scientific and } \\
\text { Technological Achievement }\end{array}$ & 0.009 \\
\hline & & Number of Prize Papers of Researchers each year & 0.006 \\
\hline & \multirow{3}{*}{$\begin{array}{l}\text { Service Satisfaction Degree } \\
(0.03)\end{array}$} & Satisfaction Degree of Scientific Research Service & 0.009 \\
\hline & & Ratios of National and Provincial Key Disciplines & 0.012 \\
\hline & & Attention Degree of governments at all levels & 0.009 \\
\hline
\end{tabular}

3) Efficiency dimension: In scientific research performance evaluation, efficiency dimension reflects the execution of scientific research management by investigating the optimization of scientific research management on funding utilization, investment, achievement output and transformation. The evaluation index of efficiency dimension consists of 3 second-level (such as efficiency, transformation efficiency of scientific research achievements and manual efficiency) and 8 thirdlevel indexes (such as the completion rate of scientific research projects, quantity growth and award rates of scientific research achievements) in "Table III".

TABLE III. EVALUATION INDEX OF EFFICIENCY DIMENSION

\begin{tabular}{|c|c|c|c|}
\hline First-level Index & Second-level Index & $\begin{array}{c}\text { Third-level Index } \\
\end{array}$ & Weight \\
\hline \multirow{8}{*}{$\begin{array}{l}\text { Efficiency } \\
\text { Dimension (0.3) }\end{array}$} & \multirow{4}{*}{$\begin{array}{l}\text { Efficiency of Scientific Research Achievements } \\
(0.09)\end{array}$} & Completion Rate of Scientific Research Projects (\%) & 0.018 \\
\hline & & Quantity Growth Rate of Scientific Research Achievements (\%) & 0.023 \\
\hline & & Award Rate of Scientific Research Achievements (\%) & 0.023 \\
\hline & & No. of Awards From Student Entrepreneurship & 0.027 \\
\hline & $\begin{array}{l}\text { Transformation Efficiency of Scientific Research } \\
\text { Achievements }(0.12)\end{array}$ & $\begin{array}{l}\text { Transformation and Application Rate of Scientific Research Achievement } \\
(\%)\end{array}$ & 0.120 \\
\hline & \multirow{3}{*}{$\begin{array}{l}\text { Manual Efficiency } \\
(0.09)\end{array}$} & No. of Core Journals per Teacher & 0.036 \\
\hline & & No. of Works per Teacher & 0.023 \\
\hline & & No. of Patents per Teacher & 0.032 \\
\hline
\end{tabular}

4) Learning and growth: Scientific research performance evaluation of application-oriented universities emphasizes learning and growth of teachers besides of scientific research funds, benefit and efficiency. Teacher is the cornerstone of long-term development of universities. High-quality teacher team is the important guarantee to enhance the comprehensive competitiveness of university. Evaluation index of learning and growth consists of 2 second-level (such as talent team construction and academic exchange) and 7 third-level indexes (such as No. of teachers selected for high-level talent pool, times of continuing education for teachers and times of developing academic forums) in "Table IV".

TABLE IV. EVALUATION INDEX OF LEARNING AND GROWTH

\begin{tabular}{|c|c|c|c|}
\hline $\begin{array}{l}\text { First-level } \\
\text { Index }\end{array}$ & $\begin{array}{l}\text { Second-level } \\
\text { Index }\end{array}$ & Third-level Index & Weight \\
\hline \multirow{7}{*}{$\begin{array}{l}\text { Learning } \\
\text { and Growth } \\
\text { Dimensions } \\
(0.2)\end{array}$} & \multirow{5}{*}{$\begin{array}{l}\text { Talent Team } \\
\text { Construction } \\
(0.12)\end{array}$} & $\begin{array}{l}\text { No. of Teachers Selected for } \\
\text { High-level Talent Pool }\end{array}$ & 0.030 \\
\hline & & $\begin{array}{l}\text { Ratio of Teachers With High- } \\
\text { grade Professional Titles }(\%)\end{array}$ & 0.024 \\
\hline & & $\begin{array}{l}\text { Ratio of "Double Qualification" } \\
\text { Teachers }(\%)\end{array}$ & 0.030 \\
\hline & & $\begin{array}{l}\text { Times of Continuing Education } \\
\text { for Teachers }\end{array}$ & 0.018 \\
\hline & & $\begin{array}{l}\text { No. of Teachers Attending } \\
\text { Professional } \\
\text { Training }\end{array}$ & 0.018 \\
\hline & \multirow{2}{*}{$\begin{array}{l}\text { Academic } \\
\text { Exchange } \\
(0.08)\end{array}$} & $\begin{array}{l}\text { Times of Attending Academic } \\
\text { Forums at Home and Abroad }\end{array}$ & 0.040 \\
\hline & & $\begin{array}{l}\text { Times of Developing Academic } \\
\text { Forums }\end{array}$ & 0.040 \\
\hline
\end{tabular}

\section{B. Index Weight Determination}

Index weight reflects the importance of index on scientific research performance evaluation. Because of the difference in the significances, the indexes are assigned with different weights, which indicate the contribution degrees of the indexes to scientific research performance evaluation. According to the characteristics of performance evaluation index system in application-oriented universities, Delphi method is used to assign the weights to evaluation indexes. Delphi method is also known as the expert opinion method. According to the evaluation index system, the experts assign the weights to the indexes with an anonymous form in "Table I" and "Table IV"). The sum of weights of all evaluation indexes is 1 .

Here we select 10 scientific research management experts of 5 application-oriented universities. According to "Scale $5 / 5-9 / 1 "$ in "Table V", the indexes at all levels are scored, and assigned with corresponding weights based on expert opinions.

TABLE V. SCALE SYSTEM 5/5-9/1

\begin{tabular}{|c|l|}
\hline Value Meaning & \multicolumn{1}{|c|}{ Scale 5/5-9/1 } \\
\hline $\boldsymbol{i}$ vs. $\boldsymbol{j}$ (same important) & $5 / 5$ \\
\hline $\boldsymbol{i}$ vs. $\boldsymbol{j}$ (slightly important) & $6 / 4$ \\
\hline $\boldsymbol{i}$ vs. $\boldsymbol{j}$ (obviously important) & $7 / 3$ \\
\hline $\boldsymbol{i}$ vs. $\boldsymbol{j}$ (strongly important) & $8 / 2$ \\
\hline $\boldsymbol{i}$ vs. $\boldsymbol{j}$ (extremely important) & $9 / 1$ \\
\hline \multirow{2}{*}{ Importance comparison between $\boldsymbol{i}$ and $\boldsymbol{j}$} & $6.5 / 3.5 \quad 5.5 / 4.5$ \\
\hline $\boldsymbol{j}$ vs. $\boldsymbol{i}$ & $7.5 / 2.58 .5 / 1.5$ \\
\hline
\end{tabular}

${ }^{\text {a. }}$ Remarks: Table 5 refers to Su Weihua, Theory and Method of Multi Index Comprehensive Evaluation, China Price Press, 2001: 152-166. 


\section{CONCLUSION}

Different from traditional performance method, BSC can be used to more comprehensively investigate scientific research management performance. The performance evaluation system of scientific research management based on BSC provides a new management mode for scientific research management, performance evaluation, resource allocation and development strategy formulation in university. The implementation effect depends on decomposition and implementation process of strategic goal of scientific research in university. It is hoped that this evaluation index system of scientific research management performance can provide beneficial reference for performance evaluation in application-oriented universities.

\section{ACKNOWLEDGEMENT}

The work was supported by Higher Education Research Foundation Project of Jiangsu University of Technology (KYY16563).

\section{REFERENCES}

[1] Su Weihua, Multi-index Comprehensive Evaluation Theory and Method, China Price Press, 2001.

[2] Zhao Bin, Luan Hong, et al., Mechanism of Innovation Behaviors of Researchers Based on Theory of Planned Behavior, Studies in Science of Science, 2013, 02.

[3] Lavie D, Haunschild P R, Khanna P, Organizational Differences, Relational Mechanisms and Alliance Performance, Strategic Management Journal, 2012, 33(13):1453-1479.

[4] Zhang Baosheng, Wu Hongyuan, University Strategy Implementation Based on BSC, Modern Education Management, 2010, 01.

[5] Bi Yiwen, Sun Yongling, Balanced Scorecard and strategy Execution Applications in China, China Machine Press, 2005.

[6] Li Shiqi, Performance Evaluation Model and Its Application of Scientific Research Project in University Based on BSC and Analytical Hierarchy Process, Education Research Monthly, 2015, 10.

[7] Li Xia, Problems and Reflections on Scientific Research Management in Application-oriented Universities, Management \& Technology of SME, 2016, 06. 